УДК 378.091.33-027.22:[613+379.83]

https://doi.org/10.33296/2707-0255-9(17)-10

https://orcid.org/0000-0003-2795-6005*

http://orcid.org/0000-0002-5874-3830**

БРИЖАК НАДІЯ*,

кандидат педагогічних наук, доцент, доцент кафедри теорії та методики початкової освіти, Мукачівський державний університет, м. Мукачево, Україна

МІШКУЛИНЕЦЬ ОЛЕНА**, кандидат психологічних наук, викладач психолого-педагогічних дисциплін ВСП Гуманітарно-педагогічний фаховий коледж Мукачівського державного університету, м. Мукачево, Україна

\title{
ПРАКТИКА В ЛІТНІХ ОЗДОРОВЧИХ ТАБОРАХ ЯК ЗАСІБ ФОРМУВАННЯ ПРОФЕСІЙНОЇ КОМПЕТЕНТНОСТІ ЗДОБУВАЧІВ ВИЩОї ОСВІТИ
}

Анотація. У статті здійснено аналіз проблеми підготовки здобувачів вищої освіти, майбутніх педагогів до практики в літніх оздоровчих таборах як засобу формування їхньої педагогічної компетентності; уточнено зміст понять «педагогічна практика», «професійна підготовка», «професійна компетентність», «літні оздоровчий табір». Аналіз літературних джерел 3 проблеми дослідження показав, що педагогічна практика (практика в літніх оздоровчих таборах) виступає обов'язковою складовою освітнього процесу педагогічних закладів освіти. Визначено, що мета підготовки студентів до роботи в літніх оздоровчих таборах полягає у розширенні професійнопедагогічних знань і досвіду самостійної організації життя і діяльності дитячого колективу, оволодіння методикою виховної роботи зі школярами різного віку в період літніх канікул. З'ясовано, що підготовка до практики в літніх оздоровчих таборах має системний характер i передбачає здійснення постійного психолого-педагогічного супроводу досвідченими викладачамиметодистами, вожатими, керівниками дитячих оздоровчих таборів.

Встановлено, що підготовка здобувачів освіти має грунтуватися на таких компонентах: особистісний, теоретичний, практичний. Уточнено, що професійна компетентність складається з різних компонентів - компетенцій, які визначають готовність i здатність майбутнього вчителя до успішного виконання професійно-педагогічної діяльності. 
Окреслено, що виховна робота в літніх оздоровчих таборах включає в себе поєднання відпочинку, праці, спорту 3 пізнавальною, естетичною, екологічною, оздоровчою діяльністю. Зміст, форми та методи роботи визначаються статутом, педагогічним колективом і будуються на принципах ініціативи й самодіяльності дітей та учнівської молоді, демократії і гуманізму, розвитку національних i культурно-історичних традицій, пріоритетності загальнолюдських духовних досягнень і цінностей.

3'ясовано, що у процесі роботи в літньому оздоровчому таборі студенти повинні проводити різні види й організаційні форми діяльності: конкурси, огляди, змагання 3 різних видів діяльності, які сприяють самовизначенню загонів, організаційно-громадську діяльність; виховні бесіди та правила 3 техніки безпеки; трудові справи, самообслуговування, чергування в їдальні, по табору, благоустрій території тощо.

Обгрунтовано, що вся робота в літньому оздоровчому таборі повинна бути ретельно спланована. Планування виховної роботи вимагає чіткої послідовності, системності та наступності. Це одна 3 найважливіших умов успішної організації літнього відпочинку школярів.

Ключові слова: практика в літніх оздоровчих таборах, літній оздоровчий табір, обов'язки студента-практиканта, професійна компетентність, здобувачі вищої освіти.

Постановка проблеми. Професійна підготовка сучасного вчителя $є$ дуже актуальною і важливоюдля українського суспільства, адже вона вирішує проблему підвищення якості організації освітнього процесу у закладах освіти.

Одним із стратегічних шляхів на сьогодні визначено компетентнісний i діяльнісний підходи до професійної підготовки здобувачів вищої освіти.

В останні роки спостерігається тенденція до зростання кількості наукових напрацювань, присвячених пошуку різноманітних підходів, технологій, аспектів конкурентоспроможності у сфері освіти, зокрема професійної підготовки. Проте ці дослідження присвячено загальним iï питанням i, як правило, пов'язані з окремими напрямами підготовки здобувачів вищої освіти.

Зазначимо, що Закон України «Про вищу освіту» (стаття 51), Положення «Про проведення практики студентів вищих навчальних закладів України» чітко регламентують отримання здобувачами освіти не лише теоретичної підготовки, але й практичної на підприємствах, установах і організаціях згідно до укладених угод [4]. Тому, актуальність проблеми дослідження зумовлена 
також тим, що саме педагогічна практика $\epsilon$ однією із ефективних форм практичної підготовки у закладі вищої освіти, оскільки грунтується на професійних знаннях, забезпечує оволодіння способами організації й здійснення майбутньої професійної діяльності.

Виходячи з цього, особливого значення набуває педагогічна практика, зокрема практика літніх оздоровчих таборах, у ході якої здобувачі освіти набувають фахові компетентності.

Аналіз останніх досліджень і публікацій. Аналіз наукової літератури 3 проблеми дослідження свідчить, що проблема формування професійної компетентності майбутнього вчителя в умовах літніх оздоровчих таборів досліджувалась багатьма науковцями, зокрема: С.Бондарь, Н.Глинянюк, Є.Павлютенков, С.Тищенко (формування професійної компетентності вчителів); Л. Іванова, Б. Кіндратюк, Л. Пундик, Л. Скорова, М. Толмачев, О. Яковліва (підготовка вихователів, помічника вихователя (вожатого) табору до роботи в літніх оздоровчих таборах); М. Дік, Е. Козлов, Л. Корнєва, А. Кузнєцов, В. Новікова, М. Сисоєва, Г. Чернишова та ін. (формування особистісних рис вихователя (вожатого) та його психолого-педагогічної готовності до роботи 3 дітьми).

Окремі питання професійної діяльності майбутніх педагогів у дитячих закладах оздоровлення та відпочинку висвітлені у дослідженнях О. Безпалько, Н. Грушевської, Л. Кириченко, Т. Тарасової, Л. Шаламової; методичні аспекти виховної діяльності представлені у роботах Ю. Григоренка, О. Дубасенюк, М. Дубінки, Д. Пенішкевич, Н. Яковець. Підготовку майбутніх фахівців до професійної діяльності в дитячих оздоровчих таборах вивчали В. Вараксін, С. Панченко, Л. Пундик, М. Фірсов. Наукові праці дослідників мають не тільки велике теоретичне, але й практичне значення для проблеми дослідження, та все ж не вичерпують іiі повністю. Оновлення потребують питання формування педагогічної компетентності здобувачів вищої освіти до проведення виховної та дозвіллєвої діяльності в оздоровчих закладах відпочинку. 
Мета статті полягає у теоретичному розкриті змісту та структури підготовки здобувачів вищої освіти (майбутніх педагогів) до практики в літніх оздоровчих таборах як засобу формування їхньої педагогічної компетентності.

У процесі дослідження проаналізовано методичну, психолого-педагогічну літературу за тематикою дослідження; використовувалися методи узагальнення, порівняння та систематизації.

Виклад основного матеріалу дослідження. Сучасний стан розвитку суспільства вимагає від педагога високого рівня професійної компетентності. За час навчання у закладі вищої освіти в майбутнього фахівця повинні бути сформовані відповідні професійно-педагогічні особливості: високий рівень фахово-теоретичної, методичної та практичної підготовки.

Як зазначає Г. Шулдик, педагогічна практика є тим містком, який пов'язує теоретичне навчання студента 3 його майбутньою роботою в школі, оскільки під час педагогічної практики не тільки відбувається перевірка теоретичної та практичної підготовки студента до самостійної роботи, але й створюються широкі можливості для забезпечення творчого потенціалу особистості майбутнього вчителя [14]. Особливу роль у цьому процесі відіграє етап професійного становлення, коли здобувачі вищої освіти проходять педагогічну практику, у процесі якої мають можливість не тільки відтворювати теоретичні знання, а й оволодівати новими технологіями навчання й виховання, формувати та досягати принципово нових цілей, що забезпечить професійну їх активність.

Академік С. Гончаренко в «Українському педагогічному словнику» наводить визначення педагогічної практики як спосіб вивчення освітнього процесу на основі безпосередньої участі в ньому практикантів [3].

Літня педагогічна практика виступає обов'язковою складовою освітнього процесу педагогічних закладів освіти. Таке твердження узгоджується зі статтями 2 та 33 Закону України «Про оздоровлення та відпочинок дітей», де зазначено, що основним напрямом державної політики у сфері оздоровлення та 
Електронне наукове фахове видання «Адаптивне управління: теорія і практика. Серія "Педагогіка"

Випуск 9(17), 2020

відпочинку дітей $є$ забезпечення підготовки кадрів для здійснення заходів 3 оздоровлення та відпочинку дітей [5].

3 метою визначення сутності та змісту підготовки здобувачів вищої освіти до роботи з дітьми в літній період, необхідно охарактеризувати специфіку роботи літніх закладів оздоровлення та відпочинку.

Виховна робота 3 учнями у літніх оздоровчих таборах $\epsilon$ частиною позашкільної освіти, яка розглядається науковцями як освітній процес, що проводяться у закладах позашкільної освіти з метою задоволення різнобічних культурних інтересів і запитів дітей, розвитку їхньої самодіяльності та творчих здібностей, розумної організації дозвілля і відпочинку.

Стратегічними орієнтирами роботи літніх оздоровчих таборів є головні законодавчі документи України: закон України «Про освіту» (2015), «Про позашкільну освіту» (2019), «Про оздоровлення та відпочинок дітей» (2008), «Типове положення про дитячий оздоровчий заклад» (2004), «Концепція позашкільної освіти та виховання» (1996), Концепція розвитку позашкільної освіти (Проект 2019).

Відповідно до Типового положення про дитячий оздоровчий заклад [12, с. 11] та Примірного положення про оздоровчий табір (містечко, комплекс) для дітей, підлітків та учнівської молоді» (п.1.1.) [8, с. 19].оздоровчий табір (заміський, профільний, праці та відпочинку, санаторного типу, з денним перебуванням тощо) $є$ позашкільним оздоровчо-виховним закладом i створюється ... 3 метою організації змістовного дозвілля і відпочинку, зміцнення здоров'я, задоволення інтересів і духовних запитів дітей, підлітків і учнівської молоді.

О. Голік та С. Харченко розглядають виховну роботу педагога як організацію дозвілля школярів. Тому дозвілля дітей у таборі повинно містити доцільне поєднання відпочинку, праці, спорту з пізнавально, естетичною, оздоровчою діяльністю [2, с. $6 ; 11$, с. 9].

Організовуючи виховну роботу 3 вихованцями в таборі, вихователь (вожатий) повинен реалізувати основні функції дозвілля, визначені $\mathrm{y}$
(C) Украйнська інженерно-педагогічна академія
(С) ГО «Школа адаптивного управління соціально-педагогічними системами»
(C) Брижак Н., Мішкулинець О. 
Електронне наукове фахове видання «Адаптивне управління: теорія і практика. Серія "Педагогіка"

Випуск 9(17), 2020

дослідженнях Ю. Бардашевської, В. Бочелюк, М. Коваля, І. Петрової, С. Шмакова, а саме: рекреаційну, комунікативну, соціальну, творчу, пізнавальну, ціннісно-орієнтаційну, виховну. Крім вказаних, С. Пащенко [7] виокремила ще й когнітивну, креативну, духовну функції, а Н. Яременко - розвивальну, оздоровчу, освітню, культурологічну, психотерапевтичну [16].

Н. Яременко вважає, що пріоритетні завдання канікулярного часу полягають у збереженні здоров'я, повноцінному відпочинку, усебічному розвитку, різноманітному дозвіллі [16, с. 53], а основними видами діяльності в таборах відпочинку є культурно-дозвіллєвий, освітньо-дозвіллєвий, дозвіллєворозважальний, дозвіллєво-ігровий [16, с. 30-31]. На нашу думку, слід додати такі види, як суспільно-корисна діяльність дітей та самообслуговування.

Ефективність організації роботи в літніх оздоровчих закладах, на думку Н. Яременко, характеризується створенням умов для виявлення та розвитку самостійності; свободи вибору видів діяльності, друзів, колективу; стимулювання пізнавальної і творчої діяльності. Життя у таборі має бути пов'язане $з$ грою, успіхом, пригодами, вибором; а також багатоманітністю творчих форм та методів виховної діяльності, відсутністю формалізму та заорганізованості [16, с. 56-57].

Робота педагога-вихователя, вожатого полягає в тому, що за порівняно короткий час, він не лише повинен товаришувати 3 дітьми, завойовувати в них авторитет, а й згуртувати, об'єднати незнайомих раніше дітей, створити дружній колектив, де б панували взаєморозуміння та взаємопідтримка. Для досягнення успіху в цій нелегкій справі потрібна грунтовна професійна підготовка.

«Енциклопедія професійної освіти» визначає «професійну підготовку» як процес професійного розвитку фахівця, що забезпечує набуття базових знань, умінь, навичок і якостей, практичного досвіду і норм поведінки, що створює умови успішної роботи у царині певної професії» [15, с. 390].

Оскільки триєдина стратегічна мета вищої освіти полягає у професіоналізації, соціалізації та самореалізації студентів, то саме їх можна 
Електронне наукове фахове видання «Адаптивне управління: теорія і практика. Серія «Педагогіка"

Випуск 9(17), 2020

вважати основою фундаментальної підготовки фахівців. Л. Хомич стверджує, що метою вищої педагогічної освіти є професійна підготовка вчителів високої кваліфікації [13, с. 111].

Заслуговує на увагу позиція В. Сластьоніна, який умовою якісної педагогічної роботи майбутнього вчителя вважає таку підготовку, яка забезпечить «професійну компетентність,... формування у студентів сучасного стилю цілісного науково-педагогічного мислення, готовності до професійної самоосвіти» $[10$, с. 63$]$.

О. Овчарук, зазначає, що «професійна компетентність - це інтегративна (системна) властивість особистості майбутнього вчителя, що характеризує його психолого-педагогічну і предметну обізнаність, професійні вміння та навички, особистісний досвід і освіченість фахівця, націленого на перспективність (прогностичність) в роботі, здатного до динамічного збагачення, а також здатного досягати високих результатів і якості в професійній діяльності» [6, c. 24-26].

Компоненти професійної компетентності здобувачів вищої освіти виділялися нами з урахуванням державних та галузевих стандартів педагогічної освіти: готовність і здатність майбутнього вчителя до успішного виконання професійно-педагогічної діяльності.

Аналіз наукових досліджень цієї проблеми дав змогу визначити, що підготовка майбутніх вчителів до роботи в літніх оздоровчих таборах становить важливу частину загальної фахової підготовки, результатом якої є позитивне ставлення до професії, усвідомлення мотивів і потреб здобувачів вищої освіти у роботі в оздоровчих таборах, наявність професійно-важливих якостей

особистості, іï соціальної зрілості, почуття відповідальності за власну діяльність, а також відповідні компетентності.

Результати дослідження. Практична підготовка здобувачів вищої освіти до роботи в літніх оздоровчих таборах у Мукачівському державному університеті та ВСП Гуманітарно-педагогічному фаховому коледжі МДУ здійснюється під час інструктивно-методичної конференції та проходження 
педагогічної практики.

Під час настановчих конференцій, індивідуальних бесід, круглих столів здобувачів вищої освіти ознайомлюють 3 специфікою роботи в літньому оздоровчому таборі, методами, видами та формами роботи 3 колективом дітей та підлітків, табірною документацією тощо.

Також зазначимо, що підготовка до педагогічної практики в літніх оздоровчих таборах має системний характер i передбачає здійснення постійного психолого-педагогічного супроводу досвідченими викладачамиметодистами, вихователями (вожатими), керівниками дитячих оздоровчих таборів, у процесі якого особлива увага приділяється педагогічним ситуаціям, які виникають у таборах, методам згуртування дитячого та вожатського колективів, методичним аспектам професійної підготовки майбутніх педагогів.

Відповідно до освітньої програми педагогічна практика (практика в літніх оздоровчих таборах) проходиться в кінці III курсу, тривалість їі складає два тижні або одну зміну в дитячому оздоровчому таборі. Студенти-практиканти розподіляються у літні табори різного типу (пришкільні табори , позаміські заклади оздоровлення та відпочинку, санаторні та спортивно-оздоровчі) міста Мукачева та області.

Для успішного проходження даного виду педагогічної практики керівництво постійно співпрацює 3 директорами пришкільних таборів, позаміських закладів оздоровлення та відпочинку, заздалегідь уклавши договір. Контроль за проходженням даного виду практики здійснюють викладачіметодисти, які відвідують табори, спортивно-оздоровчі майданчики, де перебувають студенти, перевіряють документацію, консультують їх, надають методичну допомогу.

Метою підготовки студентів до роботи в літніх оздоровчих таборах полягає у розширенні професійно-педагогічних знань і досвіду самостійної організації життя і діяльності дитячого колективу, оволодіння методикою виховної роботи зі школярами різного віку в період літніх канікул [1, с. 7]. А це, зокрема, має суттєвий вплив на якість загальнопедагогічної підготовки. 
Електронне наукове фахове видання «Адаптивне управління: теорія і практика. Серія "Педагогіка" Випуск 9(17), 2020

Основними завданнями педагогічної практики (практика в літніх оздоровчих таборах) у Мукачівському державному університеті та ВСП Гуманітарно-педагогічному фаховому коледжі МДУ є:

1) сформувати у студентів уміння і навички роботи 3 вихованцями в умовах літнього оздоровчого табору;

2) ознайомлення студентів з умовами роботи та правилами внутрішнього розпорядку оздоровчого закладу;

3) встановлення ділових контактів з колегами по роботі;

4) оволодіння методикою підготовки, організації та проведення різних форм виховної роботи з дітьми (загонового збору, вогника, лінійки, походу, екскурсії, гри, конкурсу, занять клубів, гуртків та ін.);

5) формування професійно-педагогічної спрямованості студента;

6) засвоєння інноваційних соціально-педагогічних технологій організації літнього відпочинку і оздоровлення дітей;

7) формування досвіду здорового способу життя та зміцнення здоров'я учнів;

8) розширення i поглиблення науково-теоретичних знань студентів 3 педагогіки, психології, спеціальних дисциплін в процесі проведення виховної роботи;

9) розвиток умінь вибирати найефективніші методи i прийоми колективної та індивідуальної роботи з вихованцями;

10) самоаналіз власної діяльності, відображений у педагогічному щоденнику, звіті студента-практиканта $[1$, с. 7].

Особливістю організації літньої педагогічної практики в Мукачівському державному університеті $€$ те, що ій передує значна інформаційнороз'яснювальна робота, до якої залучаються викладачі-методисти.

Після отримання допуску студенти отримують направлення на педагогічну практику в літні оздоровчі табори, де працюють на посаді педагогаорганізатора, вихователя, вожатого, фізорга, керівника гуртка, секцій, 
Електронне наукове фахове видання «Адаптивне управління: теорія і практика. Серія "Педагогіка"

Випуск 9(17), 2020

музичного керівника. Кожний практикант закріплюється на час практики за окремим загоном, групою [1, с. 11].

Розумне поєднання відпочинку, праці, спорту 3 пізнавальною, естетичною, екологічною, оздоровчою діяльністю є головною метою виховної робота в таборі відпочинку та оздоровлення. Відповідно, зміст, форми та методи роботи визначаються статутом, педагогічним колективом і будуються на принципах ініціативи й самодіяльності дітей та учнівської молоді, демократії гуманізму, розвитку національних i культурно-історичних традицій, пріоритетності загальнолюдських духовних досягнень і цінностей.

У процесі роботи в літньому оздоровчому таборі студенти повинні проводити різні види й організаційні форми діяльності:

- конкурси, огляди, змагання з різних видів діяльності, які сприяють самовизначенню загонів, що проявляють перші колективні емоції, першу спільну радість (конкурси «Кохання 3 першого погляду», «Міс та містер табору»; «Лицарський турнір», «Нумо, дівчата!», «Караоке на майдані», «Краща пропозиція»; змагання «Веселі старти»; «Що? Де? Коли?»; гра з правил дорожнього руху «Випробування на дорозі»; «Сам собі рятувальник», спортивні змагання з настільного тенісу, шахово-шашковий турнір, волейболу та футболу; конкурс малюнків на асфальті «Небезпеки, що оточують нас», конкурс поробок з природного матеріалу та ін.);

- справи комплексного характеру (день миру, день пам’яті, день журналіста, день захисту дітей, день друзів, операція «Наш друг - природа», день милосердя);

- організаційно-громадська діяльність (колективне планування діяльності загону, дружини, збір з планування роботи, участь у роботі творчих груп, ради справи);

- виховні бесіди та правила $з$ техніки безпеки («У поході»; «Сонце: наш друг та ворог», «Обережно! Отруйні гриби!», «Обережно! Не всі ягоди корисні», правила протипожежної безпеки, правила безпеки на водоймах, правила захисту від комах, кліщів, комарів; 
- проведення опитування «Ваша думка», «Що я можу зробити?»; анкетування «Хочу, щоб було так»;

- трудові справи, самообслуговування, чергування в їдальні, по табору, благоустрій території тощо.

Після закінчення педагогічної практики студент-практикант представляє звітну документацію:

1. Щоденник практики (3 характеристикою та оцінкою за практику, завірену підписом директора табору та печаткою закладу).

2. Педагогічний щоденник.

3. Звіт студента про проходження педагогічної практики.

4. План-сітку.

5. Загоновий куточок.

6. Сценарії табірної зміни (не менше 10).

7. Альбом (фотоколаж) [1, с. 15].

Підсумки педагогічної практики підводяться на заліку за участю всіх студентів та методистів. Учасники конференції виступають 3 пропозиціями щодо організації та проведення педагогічної практики з метою її вдосконалення $[9$, c. 10$]$.

Оцінювання якості проходження педагогічної практики складається із суми оцінок, які виставлені керівником від бази практики, керівником від 3ВО за виконання завдань практики та за підсумком усного захисту перед комісією основних положень, які входять до програми практики.

Вся робота в літньому оздоровчому таборі повинна бути ретельно спланована. Планування виховної роботи вимагає чіткої послідовності, системності та наступності. Це одна з найважливіших умов успішної організації літнього відпочинку школярів.

Висновки. Перспективи подальших досліджень. Отже, 3 вище викладеного можна зробити наступні висновки:

Важливим етапом у становленні та розвитку особистості дитини є iї допущенність до різноманітних видів діяльності через організацію літніх 
Електронне наукове фахове видання «Адаптивне управління: теорія і практика. Серія "Педагогіка"

Випуск 9(17), 2020

таборів, які вдало поєднують оздоровчу і виховну функції Дитячий табір створює умови для розкриття творчих сил кожної дитини, стимулює їх прояв, сприяє розвитку творчого потенціалу особистості. Узгоджена із віком творча діяльність сприяє підвищенню мотивації до праці, розвитку інтелекту, максимальному розкриттю здібностей.

Виходячи з того, що формуванню особистості сприяють не окремі заходи, а система діяльності, в якій вихованець має можливість засвоїти соціальний досвід та досягнути самореалізації, виховний процес треба будувати так, щоб перед вихованцями постійно поставали особистісно значимі, привабливі завдання, які об’єднуються певною виховною метою.

Перед педагогами оздоровчого табору стоїть завдання у максимально короткий термін організувати всі необхідні види роботи з дітьми таким чином, щоб їм захотілось повернутись до табору знову. Це означає, що були створені всі необхідні умови для набуття нового соціально-бажаного досвіду для вихованців, а час, проведений у оздоровчому таборі, був змістовним, цікавим $\mathrm{i}$ корисним для їх розвитку.

Таким чином, система професійної підготовки здобувачів вищої освіти до педагогічної практики (практики в літніх оздоровчих таборах) відіграє важливу роль. Оскільки, вона не лише розширює, поглиблює та закріплює психологопедагогічні знання майбутніх вихователів (вожатих), а й створює умови для набуття ними досвіду самостійної організації життя та діяльності тимчасового дитячого колективу під час літнього відпочинку, сприяє удосконаленню їх конструктивних, організаторських, комунікативних, творчих умінь, готує до виконання виховних функцій тощо.

Перспективами подальших розвідок 3 питання підготовки здобувачів вищої освіти до практики в літніх оздоровчих таборах як засобу формування їхньої педагогічної компетентності має стати обгрунтування найбільш доречних та актуальних методів, видів і форм згуртування дитячого та підліткового колективів в умовах табору відпочинку. 


\section{ВИКОРИСТАНІ ДЖЕРЕЛА}

1. Брижак Н.Ю. Педагогічна практика (практика в літніх оздоровчих таборах): програма та методичні рекомендації щодо організації і проведення практики для студентів денної та заочної форм навчання спеціальності 013 «Початкова освіта» ОС «Бакалавр» / укладачі Т. І. Молнар, Н. Ю. Брижак. Мукачево: МДУ, 2020. - 55 с.

2. Голік О. Б. Підготовка майбутніх учителів до організації позакласної дозвіллєвої діяльності старшокласників : автореф. дис. на здобуття наук. ступеня канд. пед. наук : спец. 13.00.04. «Теорія та методика професійної освіти» / О. Б. Голік. - Луганськ, 2007. - 22 с.

3. Гончаренко С. У. Український педагогічний словник / С. У. Гончаренко. - К. : «Либідь», 1997. - 374 с.

4. Закон України «Про вищу освіту» від 01.07.2014 № 1556-VII [Електронний pecypc]. - Режим доступу: http://zakon4.rada. gov.ua/laws/show/1556-18

5. Закон України «Про оздоровлення та відпочинок дітей» / Відомості Верховної Ради України [Електронний ресурс]. - Режим доступу: http://zakon.rada.gov.ua/laws/show/375-17

6. Компетентнісний підхід у сучасній освіті: світовий досвід та українські перспективи / за заг. ред. О. В. Овчарук. Київ : К.І.С, 2004. 112 с.

7. Пащенко С. Ю. Підготовка соціальних педагогів до організації освітньо-дозвіллєвої діяльності учнівської молоді : автореферат дис. ... канд. пед. наук : 13.00 .04 / Світлана Юріївна Пащенко / Національний педагогічний університет імені М. П. Драгоманова. - Київ, 2000. - 19 с.

8. Примірне положення про оздоровчий табір (містечко, комплекс) для дітей, підлітків та учнівської молоді // Все для вчителя. - 2001. - С. 19-20.

9. Програма педагогічної практики (практики в літніх оздоровчих таборах) для студентів спеціальності 013 «Початкова освіта» ОС «Бакалавр». Мукачево: МДУ, 2019. - 15 с.

10. Сластенин В. А. Формирование личности учителя советской школы в процессе профессиональной подготовки / В. А. Сластенин. - М. : «Просвещение», 1976. - 160 с.

11. Соціально-педагогічна діяльність у дитячих оздоровчих таборах : навч.-метод. посіб. для фахівців та студентів - організаторів літнього відпочинку дітей та молоді / За заг.ред. С. Я. Харченка; Авт. кол. : С. Я. Харченко, Л. Ц. Ваховський, О. П. Песоцька та ін. - Луганськ : Альмаматер, 2008. - 285 с.

12. Типове положення про дитячий оздоровчий заклад // Завуч. - 2006. № 12 (270) квітень.- С. 3-14.

13. Хомич Л. О. Професійно-педагогічна підготовка вчителя початкових класів : монографія / Л. О. Хомич. - К. : Магістр-S, 1998. - 200 с.

14. Шулдик Г.О., Шулдик В.I. Педагогічна практика: Навчальний 
посібник для студентів педагогічних вузів. - К.: Науковий світ, 2000. - 143 с.

15. Энциклопедия профессионального образования : В 3-х т. : Т.2. / Под ред. С. Я. Батышева. - М. : АПО, 1999. - 440 с.

16. Яременко Н. В. Дозвіллєзнавство : навч. посіб. / Н. В. Яременко. Фастів : Поліфаст, 2007. - 460 с.

\section{REFERENCES}

1. Bryzhak N.Iu. Pedahohichna praktyka (praktyka v litnikh ozdorovchykh taborakh): prohrama ta metodychni rekomendatsii shchodo orhanizatsii i provedennia praktyky dlia studentiv dennoi ta zaochnoi form navchannia spetsialnosti 013 «Pochatkova osvita» OS «Bakalavr»/ ukladachi T. I. Molnar, N. Yu. Bryzhak. Mukachevo: MDU, 2020. $-55 \mathrm{~s}$.

2. Holik O. B. Pidhotovka maibutnikh uchyteliv do orhanizatsii pozaklasnoi dozvillievoi diialnosti starshoklasnykiv : avtoref. dys. na zdobuttia nauk. stupenia kand. ped. nauk : spets. 13.00.04. "Teoriia ta metodyka profesiinoi osvity» / O. B. Holik. - Luhansk, 2007. - 22 s.

3. Honcharenko S. U. Ukrainskyi pedahohichnyi slovnyk / S. U. Honcharenko. - K. : «Lybid», 1997. - 374 s.

4. Zakon Ukrainy «Pro vyshchu osvitu» vid 01.07.2014 № 1556-VII [Elektronnyi resurs]. - Rezhym dostupu:

http://zakon4.rada.gov.ua/laws/ show/ 1556-18

5. Zakon Ukrainy «Pro ozdorovlennia ta vidpochynok ditei»/ Vidomosti Verkhovnoi Rady Ukrainy [Elektronnyi resurs]. - Rezhym dostupu: http://zakon.rada.gov.ua/laws/show/375-17

6. Kompetentnisnyi pidkhid u suchasnii osviti: svitovyi dosvid ta ukrainski perspektyvy / za zah. red. O. V. Ovcharuk. Kyiv : K.I.S, 2004. 112 s.

7. Pashchenko S. Yu. Pidhotovka sotsialnykh pedahohiv do orhanizatsii osvitno-dozvillievoi diialnosti uchnivskoi molodi : avtoreferat dys. ... kand. ped. Nauk 13.00.04 / Svitlana Yuriivna Pashchenko / Natsionalnyi pedahohichnyi universytet imeni M. P. Drahomanova.- Kyiv, 2000. - 19 s.

8. Prymirne polozhennia pro ozdorovchyi tabir (mistechko, kompleks) dlia ditei, pidlitkiv ta uchnivskoi molodi // Vse dlia vchytelia. - 2001. - S. 19-20.

9.Prohrama pedahohichnoi praktyky (praktyky $\mathrm{v}$ litnikh ozdorovchykh taborakh) dlia studentiv spetsialnosti 013 «Pochatkova osvita» OS «Bakalavr». Mukachevo: MDU, 2019. - 15 s.

10. Slastenyn V. A. Formyrovanye lychnosty uchytelia sovetskoi shkolы v protsesse professyonalnoi podhotovky / V. A. Slastenyn. - M. : «Prosveshchenye», 1976. $-160 \mathrm{~s}$.

11. Sotsialno-pedahohichna diialnist u dytiachykh ozdorovchykh taborakh : navch.-metod. posib. dlia fakhivtsiv ta studentiv - orhanizatoriv litnoho vidpochynku ditei ta molodi / Za zah.red. S. Ya. Kharchenka; Avt. kol. : S. Ya. Kharchenko, L. Ts. Vakhovskyi, O. P. Pesotska ta in. - Luhansk : Alma-mater, 2008. - 285 s.

12. Typove polozhennia pro dytiachyi ozdorovchyi zaklad // Zavuch. - 2006. - 
№ 12 (270) kviten.- S. 3-14.

13. Khomych L. O. Profesiino-pedahohichna pidhotovka vchytelia pochatkovykh klasiv : monohrafiia / L. O. Khomych. - K. : Mahistr-S, 1998. - 200s.

14. Shuldyk H.O., Shuldyk V.I. Pedahohichna praktyka: Navchalnyi posibnyk dlia studentiv pedahohichnykh vuziv. - K.: Naukovyi svit, 2000. - $143 \mathrm{~s}$.

15. Эntsyklopedyia professyonalnoho obrazovanyia: V 3-kh t. : T.2. / Pod red. S. Ya. Batisheva. - M. : APO, 1999. - 440 s.

16. Yaremenko N. V. Dozvillieznavstvo : navch. posib. / N. V. Yaremenko. Fastiv : Polifast, 2007. $-460 \mathrm{~s}$.

\author{
NADIIA BRYZHAK \\ candidate of pedagogical sciences, \\ associate professor, associate professor \\ of department of theory and \\ methodology of primary education \\ Mukachevo State University, \\ Mukachevo, Ukraine \\ OLENA MISHKULYNETS \\ candidate of Psychological Sciences, \\ teacher of psychological and pedagogical \\ disciplines \\ VSP Humanitarian - pedagogical vocational \\ college \\ Mukachevo State University \\ Mukachevo, Ukraine
}

\title{
PRACTICE IN SUMMER HEALTH CAMPS AS A MEANS OF FORMING PROFESSIONAL COMPETENCE OF HIGHER EDUCATION
}

\begin{abstract}
The article analyzes the problem of preparing higher education applicants, future teachers for practice in summer health camps as a means of forming their pedagogical competence; the content of the concepts "pedagogical practice", "summer health camps", "professional competence" is specified. It is established that pedagogical practice (practice in summer health camps) is a mandatory component of the educational process of pedagogical educational institutions. It is determined that the purpose of preparing students to work in summer health camps is to expand professional and pedagogical knowledge and experience of independent organization of life and activities of children's team, mastering the methods of educational work with students of different ages during the summer holidays. It was found that preparation for practice in summer health camps has a systemic nature and involves the implementation of constant psychological and pedagogical support by experienced teachers, methodologists, counselors, leaders of children's health camps.

It is established that the training of students should be based on the following components: personal, theoretical, practical. It is specified that professional
\end{abstract}


competence consists of various components - competencies that determine the readiness and ability of the future teacher to successfully perform professional and pedagogical activities.

It is outlined that the educational work in the camp includes a reasonable combination of rest, work, sports with cognitive, aesthetic, environmental, health activities. The content, forms and methods of work are determined by the statute, teaching staff and are based on the principles of initiative and initiative of children and students, democracy and humanism, development of national and culturalhistorical traditions, priority of universal spiritual achievements and values.

It was found that in the process of working in the summer health camp, students must conduct various types and organizational forms of activity: competitions, reviews, competitions in various activities that promote self-determination of units, organizational and social activities; educational conversations and safety rules; labor affairs, self-service, duty in the dining room, camp, landscaping, etc.

It is substantiated that all work in the summer health camp should be carefully planned. Planning educational work requires a clear sequence, system and consistency. This is one of the most important conditions for the successful organization of summer holidays for schoolchildren.

Keywords: practice in the summer health camp, summer recreation camp, duties of student-trainee, professional competence, applicants for higher education.

\title{
БРИЖАК НАДЕЖДА,
}

кандидат педагогических наук, доцент, доцент кафедры теории и методики начального образования, Мукачевский государственный университет, г. Мукачево, Украина

\section{МИШКУЛИНЕЦЬ ЕЛЕНА,}

кандидат психологическихнаук, преподаватель психолого-педагогических дисциплин ОСП Гуманитарно-педагогический профессиональный колледж

Мукачевского государственного университета, г. Мукачево, Украина

\section{ПРАКТИКА В ЛЕТНИХ ОЗДОРОВИТЕЛЬНЫХ ЛАГЕРЯХ КАК СРЕДСТВО ФОРМИРОВАНИЕ ПРОФЕССИОНАЛЬНОЙ КОМПЕТЕНТНОСТИ СОИСКАТЕЛЕЙ ВЫСШЕГО ОБРАЗОВАНИЯ}

\begin{abstract}
Аннотация. В статье проведен анализ проблемы подготовки соискателей высшего образования, будущих педагогов к практике в летних оздоровительных лагерях как средства формирования их педагогической компетентности; уточнено содержание понятий «педагогическая практика»,
\end{abstract}


«летние оздоровительные лагеря», «профессиональная компетентность». Установлено, что педагогическая практика (практика в летних оздоровительных лагерях) выступает обязательной составляющей образовательного процесса педагогических учебных заведений. Определено, что цель подготовки студентов к работе в летних оздоровительных лагерях заключается в расширении профессионально-педагогических знаний и опыта самостоятельной организации жизни и деятельности детского коллектива, овладение методикой воспитательной работы со школьниками разного возраста в период летних каникул. Выяснено, что подготовка к практике в летних оздоровительных лагерях носит системный характер и предусматривает осуществление постоянного психолого-педагогического сопровождения опытными преподавателями-методистами, вожатыми, руководителями детских оздоровительных лагерей.

Установлено, что подготовка соискателей образования должна основываться на таких компонентах: личностный, теоретический, практический. Уточнено, что профессиональная компетентность состоит из различных компонентов - компетенций, определяющих готовность и способность будущего учителя к успешному выполнению профессиональнопедагогической деятельности.

Определено, что воспитательная работа в лагере включает в себя разумное сочетание отдыха, труда, спорта с познавательной, эстетической, экологической, оздоровительной деятельностью. Содержание, формы и методы работы определяются уставом, педагогическим коллективом и строятся на принципах инициативы и самодеятельности детей и учащейся молодежи, демократии и гуманизма, развития национальных и культурно-исторических традиций, приоритетности общечеловеческих духовных достижений и ценностей.

Установлено, что в процессе работы в летнем оздоровительном лагере студенты должны проводить различные виды и организационные формы деятельности: конкурсы, смотры, соревнования по различным видам деятельности, которые способствуют самоопределению отрядов, проявляют первые коллективные эмоции, первую общую радость; организационнообщественную деятельность; воспитательные беседы и правила по технике безопасности; трудовые дела, самообслуживание, дежурство в столовой, по лагерю, благоустройство территории и тому подобное.

Обосновано, что вся работа в летнем оздоровительном лагере должна быть тщательно спланирована. Планирование воспитательной работы требует четкой последовательности, системности и преемственности. Это одно из важнейших условий успешной организации летнего отдыха школьников.

Ключевые слова: практика в летних оздоровительных лагерях, летний оздоровительный лагерь, обязанности студента-практиканта, профессиональная компетентность, соискатели высшего образования. 